\title{
Saint Jerome's Posthumous Life: Aspects of His Reception in the Twentieth Century
}

\section{Filomena Giannotti}

When Saint Jerome died 1600 years ago, he did not have anyone considered a biographer ex officio, as Ambrosius did with Paulinus or as Augustine did with Possidius.

Nevertheless, a wide variety of different materials was collected between the eighth and the thirteenth centuries. These materials, partly derived from Saint Jerome's works and legends, ${ }^{1}$ converged in the Speculum Historiale by Vincentius Bellovacensis ${ }^{2}$ and the Legenda Aurea by Jacobus de Voragine. ${ }^{3}$ Then the cult of the Saint was further developed until the sixteenth century through additional materials. ${ }^{4}$

* University of Siena - DFClam (Dipartimento di Filologia e Critica delle Letterature Antiche e Moderne); filomenagiannotti@gmail.com.

1 See Vaccari, "Le antiche vite"; Lanzoni, "La leggenda"; Cavallera, Saint Jérôme, vol. II, 135 ff.; Morisi Guerra, "La leggenda"; Morisi Guerra, Erasmo, Vita di San Girolamo, $14 \mathrm{ff}$., and Clausi, Ridar voce, $105 \mathrm{ff}$. Cf. also Larbaud, Sotto la protezione, 19. See also "Bibliotheca Hagiographica Latina Manuscripta," UCL, available online.

2 See "Bibliotheca mundi. Vincentii Burgundi [...] Speculum quadruplex, Naturale, Doctrinale, Morale, Historiale, in quo totius naturae historia, omnium scientiarum encyclopedia, moralis philosophiae thesaurus, temporum et actionum humanarum theatrum [...] exhibetur [...] Opera et studio theologorum benedictinorum collegii Vedastini in [...] Academia duacensi," Bibliothèque nationale de France, available online.

See Maggioni, Iacopo da Varazze, Legenda aurea.

4 Besides the corpus of Eusebius Cremonensis' supposed letters to Pope Damasus about Jerome's death, and Augustine's letter to Cyrillus Alexandriae with his reply (vol. 22 of Patrologia Latina by Migne, 237 ff.: see Lanzoni, "La leggenda," $37 \mathrm{ff}$.), there is also De sancto Hyeronimo by Pietro Calo from Chioggia and the 
According to Ferdinand Cavallera, one of Jerome's key modern biographers, the modern approach to Jerome began with Hieronymi Stridonensis Vita, written by Erasmus of Rotterdam as a preface to his commentary on the letters of the Saint. The Hieronymi Stridonensis Vita was first published in 1516 in Basilea and then revised and corrected in $1524 .^{5}$

Erasmus' biography aimed to do justice to the many legends about the Saint once and for all. Through his biography, Erasmus wanted to recreate Jerome's existential adventure based on his account as much as possible. Therefore, Erasmus did not mention aspects that were not considered to be relevant; for instance, the presence, by Jerome's side, of a domestic lion, grateful to the Saint who healed a thorn wound on his paw. In addition, Erasmus aimed to refute many of the hagiographic inferences related to the Saint, such as his appointment as a cardinal.

Erasmus Vita is also a passionate apology for Jerome's work as a response to all the misunderstandings, smears, and allegations he had been a victim since the time of his Roman detractors and the controversy with Rufinus. Erasmus passion in defending his hero can probably be explained by identifying many of his own features as a Christian humanist, with the characteristics of Jerome, the most learned and humanistic among the Fathers.

Four centuries later, a similar enthusiasm and an analogous projection of personal individuality on the Saint's figure inspired another work that inaugurates Jerome's reception into the twentieth century: Sous l'invocation de Saint Jérôme by Valery Larbaud. The work had a complex and very long genesis. ${ }^{6}$ For over fifty years, Larbaud traveled tirelessly and applied himself to literary and translation tasks, ranging from Whitman and Joyce to Gomez de la Serna and Reyes and from Svevo to Bacchelli (to mention the most famous writers). At the same time, he had the idea of dedicating several essays to this vital section of Jerome's production, such as that of translation. In this way, various drafts of the work under consideration were created, as he claimed, to

Catalogus sanctorum et gestorum eorum by Pietro de Natalibus (see Clausi, Ridar voce, 113-114), and above all Hieronymianus by Giovanni d'Andrea, who fixed the iconographic rules about Saint Jerome (see Lanzoni, "La leggenda," 37; Morisi Guerra, "La leggenda," 8 ff.; Morisi Guerra, Erasmo, Vita di San Girolamo, 16, and Clausi, Ridar voce, 114).

5 See Morisi Guerra, Erasmo, Vita di San Girolamo.

6 See Colesanti, “Geronimopoli”; Chevalier, Valery Larbaud, and Mousli, Valery Larbaud. Larbaud's quotes are taken from the French edition of 1997 (Larbaud, Sousl'invocation). 
placer toutes nos réflexions à propos des traducteurs, et de l'art de traduire, et de toutes les questions littéraires, morales, philologiques, techniques, qui se rattachent à cet art, Sous l'invocation de Saint Jérôme, [...] considéré comme le patron (au plein sens du mot) des traducteurs : ici-bas leur modèle ; du ciel, leur protecteur. ${ }^{7}$

The book about Saint Jerome took on quite a peculiar appearance that makes it difficult to classify. Not merely an imaginative essay, it can be described as an intellectual biography of Jerome or as a pictorial review (with many iconographic references) or as a travel book, organized as a rêverie. The last aspect seems predominant because of its articulation in three different itineraries.

The first is the physical itinerary that, even if only in his imagination, winds through the actual places related to the saint's life and worship: Stridon, Bethlehem, and Rome. In Rome, the Saint "est resté présent par sa gloire," between Santa Maria Maggiore (where he is buried) and the other churches where his worship is still alive: Sant'Onofrio al Gianicolo, San Girolamo Dottore or della Carità, and San Girolamo degli Schiavoni. ${ }^{8}$

The second itinerary is iconographic, ranging from portraits by Correggio, Raffaello, and Domenichino. Literary comparisons sometimes enrich this short pictorial review. An example is provided by the comparison between the painting Disputa del Sacramento by Raffaello and the one that Larbaud describes as "la phrase toujours citée de Sulpice Sévère sur Jérôme." Since Sulpicius Severus portrayed Jerome in his Dialogi 1.8-9, the line Larbaud is probably referring to is the passage totus semper in lectione, totus in libris est: non die neque nocte requiescit: aut legit aliquid semper aut scribit (1.9.5).

The third and last itinerary presents the ingenious idea about Hiéronymopolis, which transforms the essay about Jerome into a sort of visit to a large city named after the Saint. The exploration of Hiéronymopolis begins from the city center, represented by his work as a polemicist, author of handbooks, hagiographer, and letter-writer. This is usually neglected in favor of his translation work. The longest journey in Hiéronymopolis is transversal, which involves several letters, including the famous one to Pammachius about translation (Ep. 57). Through this last letter, also known as De optimo genere interpretandi, it is possible to enter the area "qu'on peut appeler « des étrangers na-

9 Ibid., 36. 
turalisés » ou "des métèques », le vaste Xénodochium hiéronymien: son œuvre de traducteur." ${ }^{\prime 10}$ Here, Hiéronymopolis becomes visible with all its monumental splendor,

entourée de deux enceintes concentriques : l'une basse, très endommagée, presque écroulée : sa révision de l'Itala, une des premières versions latines de la Bible ; l'autre, au contraire, puissante, épaisse, élevée, d'un aspect imposant : la Vulgate. Deux hautes tours dominent ces murailles: le Psautier gallican et le Psautier romain. ${ }^{11}$

Larbaud adds to this another building metaphor: the Vulgata can be contemplated as "le large viaduc qui relie Jérusalem à Rome." Even if the one who built this bridge, the greatest and most influential translation work ever written, was never elected Pope, he can be rightfully defined as an authentic Pontifex. ${ }^{12}$

Some decades after Larbaud's essay, Jerome finds himself as a protagonist of a novel, published by Jean Marcel in 1990: Jérôme ou De la traduction. The author's full name is Jean-Marcel Paquette (1941-2019). He was a Canadian writer and a Medieval history teacher and was awarded several prizes. ${ }^{13}$ The novel about Jerome is part of a Late Antiquity triptych, also including the characters Hypatia and Sidonius Apollinaris. ${ }^{14}$ Here Marcel is perfectly at ease among historical sources by rewriting and recreating them with fantasy and from original points of view.

An excellent example of this often brilliant and ironic style is the unique narrator, a character who, according to the legend, lived by Jerome's side for a long time. One can easily recognize the figure in all the paintings portraying the Saint - namely, his lion. The lion tells the story backward, describing the life he had by his owner's side until Jerome's death when he buried him (the novel begins at this point). The lion decides to set down his story in writing and begins to Victor-Barbeau (2000), son roman Hypatie ou la fin des dieux, le prix Molson de l'Académie des lettres du Québec (1989), et Le joual de Troie, le prix France-Québec (1973)."

14 Tryptique des Temps Perdus (Marcel, Hypatie; Marcel, Jêrome; Marcel, Sidoine). See Giannotti, Nei pensieri, 127-131, in particular note 45, and Giannotti, "Sidonius Reception," $\$ 2.1$. Quotes from Marcel, Jêrome. 
study the Saint's papers. So he starts studying the Greek, Latin, and Hebrew alphabets, and he learns to write (he is left-handed due to the famous thorn in his paw). Although he has become multilingual, he wants to write in that language "qu'à la longue je me suis composée de toutes les autres et que j'appelle le léonais." ${ }^{15} \mathrm{He}$ is leaving to posterity the memories of his unusual adventure and sorting out, at the same time, the owner's confusing life events. The narrator realizes that he is a fairytale character who found himself by the Saint's side due to hagiographic circumstances. He also recalls serving another anchorite, Gerasimos, as Iohannes Moschos writes in The Spiritual Meadow. ${ }^{16}$ The 107th chapter presents the story of a lion rescued by Saint Gerasimos, an anchorite living between Jerusalem and the desert of the Dead Sea, who extracts the thorn from his paw. After his recovery, the lion remains at the service of the hermits. Two centuries after Moschos' death, between the eighth and the ninth century, an inexperienced compiler, while working on the Latin translation, confuses the names of Gerasimos and Jerome in the Latin version of The Spiritual Meadow. ${ }^{17}$ Moreover, in approximately 1341, a thousand years after the birth of Jerome, a devotee of the Saint, and professor of Law at the University of Bologna, Giovanni d'Andrea, wrote The Life of Saint Jerome and, to spread the worship of the Saint and his image, he called the most famous painters from Bologna. After fixing the iconographic criteria, he commissioned two paintings: Jerome, penitent in the desert, and Jerome, the translator in his cave. From that point on, the lion always appears in paintings. He will start traveling through Europe, meeting famous artists such as Leonardo (who painted him at least three times), visiting some of the most famous museums in Vienna, Washington, and worldwide. However, all this throws him into a profound identity crisis.

Marcel, Jêrome, 35 .

The Greek version of The Spiritual Meadow can be read, even in a philologically approximate form, in vol. 87.3 of Migne's Patrologia Graeca (2851-3112); see also Maisano, Giovanni Mosco, Il prato.

17 The first work confusing the two names is the so-called life Plerosque nimirum (n. 3871 of the Bibliotheca Hagiographica Latina mentioned above and marked with I in Vaccari "Le antiche vite," which dates it to the end of the ninth century). For its derivation from the legend of Gerasimo (who died about $475 \mathrm{AD}$ ), see Vaccari, "Le antiche vite," 12-14, and Lanzoni, "La leggenda," 33 ff. For the Speculum Historiale, see p. 623 of the edition already mentioned above in note 2. For Iacopo da Varazze, see De sancto Hieronymo in Maggioni, Iacopo da Varazze, Legenda aurea, 142, 54 ff. (pp. 1005 ff.), with further bibliographical references. 
As the subtitle suggests - Jérôme ou De la traduction - translation is one of the main themes in the novel. This is a theme that Marcel could not avoid since this aspect represents both a turning point for the character and the activity that summarizes his importance. Of course, Marcel could not help measuring himself with the letter to Pammachius, usually entitled De optimo genere interpretandi, and writes a few pages about that. According to Marcel's intentional process of exaggeration, the lion claims that the famous method non verbum e verbo sed sensum exprimere de sensu would convince Jerome to believe that translating would eventually cause him to substitute the author with himself. Although he did not expect to replace God himself, he did so with those through whom God had spoken. This aspect of Jerome's personality is not limited to evaluating methodical issues, though it is relevant and vital. According to Marcel, Jerome's operation appears to be like the transfer of one entire world to another, in other words, like the transfer of the Ancient Orient, rock by rock, to the young Rome of Christianity. So this 'translation' can be considered a broader and more general translation from the old to the new.

On the other hand, after reflection, everything in our lives and everything surrounding us is translation. As Marcel writes in one of his digressions, even the starry sky is an "immense traduction d'un rêve. ${ }^{{ }_{18} 8}$ Nevertheless, in his titanic effort and daily struggle with the thousands of possible word interpretations, Jerome had to develop - according to his lion - not the certainties he already had but a progressive awareness of the relativity of human things. There is no such thing as a perfect translation, but only translations that are less imperfect than others. Even one of the most remarkable translations, such as Jerome's scriptures, does not escape the siege of the vanitas vanitatum. It ends up being precarious and in line with the general decline that marked the period in which Jerome carried out his activities.

If he had been living a few years after 1990, Marcel's lion could have also boasted of a celluloid life, telling us about the subject of the third part of this paper: after an essay and a novel, there is a movie: São Jerônimo. It was produced in 1999 and presented at the 2002 Turin Film Festival and then published in Italy in vHs by San Paolo Edizioni in 2004.

The direction, the subject, and the screenplay are all signed by the Brazilian Júlio Bressane, who has dedicated several films to the 
culture of his own country and whose poetic cinematography is based on three fundamental principles: ${ }^{19}$

1. intersemiotic translation, or transposition from one language to another, from the text to the movie;

2. multidisciplinarity, or the overlapping of the arts, with literature in a prominent position;

3. what Bressane calls "cinemancia," or the magical art of understanding and capturing light and the illusion of movement. In other words, according to Bressane, "la traduzione nel cinema si fa con luce-movimento-angolazione-montaggio." ${ }^{20}$

Among his films, Cleopatra, an iconography of the ancient queen, deserves mention since all of the two hundred sequences refer to as many paintings.

In this perception of cinema, the concept of "translation" among various arts naturally meets the figure of Jerome, the translator par excellence. So, it is a small step from the "primo dei nostri grandi umanisti ad affrontare la questione della traduzione" to the cinema, "dove tutto si traduce.".

As for the plot, which is quite plain, it should be noticed that in the film, the events of Jerome's life are radically simplified, even though Bressane himself claimed that he spent five years studying Jerome's works and the iconography related to the Saint. ${ }^{22}$ Therefore, it is somewhat natural that the script occasionally resorts to Jerome's works.

An excellent example is one of the first scenes in which Jerome beats himself with a stone - in line with a common theme of his iconography (for instance, in San Girolamo penitente by Lorenzo Lotto painted in 1520) - and a voiceover reads several passages from the famous Ep. 22, about the vision or dream, with the accusation: Ciceronianus es, non christianus.

The simplification previously mentioned depends on the fact that the entire biography of the Saint has been reconstructed along two main lines.

The first one is to adapt Jerome's story to the cinema and to an uninterrupted sequence of highly detailed images that gives the vi-

19 For Bressane, see Fina and Turigliatto, Júlio Bressane. See also Bressane, Dislimite.

20 On "cinemancia," see Bressane, Cinemancia; cf. Fina and Turigliatto, Júlio Bressane, 47-49.

21 Fina and Turigliatto, Júlio Bressane, 25.

22 Ibid., 235-323. 
ewer the impression of passing through a gallery with the paintings of the Saint's life (rather than through his biography).

The second one is to place symbols before actual events. So the movie proceeds through juxtaposed scenes and iconic symbols, some of which are intensely evocative. This is the case of the landscapes where most of the movie (shot in the Brazilian Sertão) is set, with blue skies, enormous boulders, and deserts inhabited only by snakes, scorpions, and spiders. This is a way to make mortification and ascesis tangible since the enormous boulder mentioned above seems almost to be presented as a symbol of God. At the same time, a voiceover blames Jerome for his proud attitude towards other hermits. From the beginning, the soundtrack is dominated by the wind; however, the scarce vegetation does not move. What matters is to evoke the idea of discomfort and inner torment. Other iconic symbols are those traditionally related to Jerome: the skull, the symbol of human transience and of the invitation to a constant meditatio mortis, which is evoked both by the aforementioned boulder and by some round ponds excavated in the desert rock by erosive agents, is also sometimes put on the Saint's papers.

The lion appears intermittently in the desert and even in Rome and in Marcella's villa, without disturbing those present. He might be considered a symbol of Jerome's inner condition, perhaps a connection to the desert. An idea is reinforced by the fact that an identical shot of Jerome follows a close-up shot of the lion's profile in the movie. Even the books need to be interpreted from a symbolic point of view: Jerome often proceeds across the desert carrying enormous manuscripts and giving the evocative impression that he is bearing a cross. ${ }^{23}$

To conclude, once again, one should mention Larbaud and one of his unusual ideas: the translator's prayer. This prayer is to be said to Saint Jerome before opening the dictionary and starting any new translation (mentally kneeling in front of his grave in Santa Maria Maggiore in Rome). This is, actually, a meagre hundredth of Jerome's quotations: ${ }^{24}$ who noted how the Saint bears them "come una croce"; Fina and Turigliatto, Júlio Bressane, 224. 
Le début sera le même que celui de la prière que lui adresse l'Église entière le 30 septembre, et qui se trouve au Commun des Docteurs: O Doctor Optime... etc., et auquel nous ajouterons d'abord les quatre premiers mots de la phrase finale de la Lettre CxL : Aggrediar opus difficillimum... ; puis la fin de sa Préface au Pentateuque : Nunc te precor... ut me... orationibus tuis juves, quo possim eodem spiritu quo scripti sunt libri in Latinum transferre sermonem. Bien entendu nous dirons, au lieu de "Latinum »: Gallicum (ou tout autre adjectif tiré du nom de la nation dans l'idiome de laquelle nous traduisons). Et, mis en français, l'ensemble donnera ceci: Docteur excellent, lumière de la sainte Église, bienheureux Jérôme, je vais entreprendre une tâche pleine de difficultés, et dès à présent, je vou supplie de maider par vos prières, afin que je puisse traduire en français cet ouvrage avec l'esprit même dans lequel il a été composé. Ainsi, à partir de l'instant où il est nommé jusqu'au point final, il n'y a pas un mot qui ne soit de lui-même. Nous le citons en lui parlant. Et quel auteur, si rassasié de louanges et de gloire qu'il soit, pourrait, même au paradis, accueillir avec indifférence un pareil compliment?

The Saint's reply does not take long to arrive:

Il comprend aussitôt que ce sont des clients exceptionnels qui s'adressent à lui, des suppliants, qui ont acquis des droits tout particuliers à sa bienveillance et à sa protection. Du haut des cieux, entouré de sa cour d'anges philologues, grammairiens et lexicographes, plus beaux que ceux du Corrège, et qui travaillent, sous sa direction, au Dictionnaire sempiternel de toutes le langues qu'ont parlées, parlent et parleront les enfants d'Adam, il nous écoute avec faveur; il nous fait signe qu'il consent; il sourit : Et pour les citations, merci. - Salut dès cette vie, et salut aux siècles des siècles, ô notre ami des cieux ! 


\section{BIBLIOGRAPHY}

Bressane, Júlio. Alguns. Rio de Janeiro: Imago Editora, 1996.

- Cinemancia. Rio de Janeiro: Imago Editora, 2000.

- Dislimite: Scritti. Piacenza: CaratteriMobili, 2014.

Cavallera, Ferdinand. Saint Jérôme: Sa vie et son oeuvre; Première Partie, Tome I-II. Louvain: Bureau du Spicilegium sacrum Lovaniense and Champion, 1922.

Chevalier, Anne, ed. Valery Larbaud. Paris: Éditions de l'Herne, 1992.

Clausi, Benedetto. Ridar voce all'antico padre: L'edizione erasmiana delle lettere di Girolamo. Soveria Mannelli: Rubbettino editore, 2000.

Colesanti, Massimo. “Geronimopoli." In Sotto la protezione di San Girolamo, edited by Valery Larbaud, 77-86. Palermo: Sellerio, 1989.

Fina, Simona, and Roberto Turigliatto, eds. Júlio Bressane. Torino: Film Festival Editore, 2002.

Giannotti, Filomena. Nei pensieri degli uomini: Momenti della fortuna di Ambrogio, Girolamo, Agostino. Bologna: Pàtron, 2009.

—_. "Sidonius Reception: Late Nineteenth to Twenty-First Centuries." In Edinburgh Companion to Sidonius Apollinaris, edited by Gavin Kelly and Joop A. van Waarden, 705-729. Edinburgh: Edinburgh University Press, 2020.

Lanzoni, Francesco. "La leggenda di San Girolamo." In Miscellanea Geronimiana, Scritti varii pubblicati nel XV centenario dalla morte di san Girolamo, con introduzione di Vincenzo Vannutelli, edited by Vicenzo Vannutelli, 19-42. Rome: Tipografia Poliglotta Vaticana, 1920.

Larbaud, Valery. Sotto la protezione di San Girolamo. Translated by Anna Zanetello. Palermo: Sellerio, 1989. First edition Paris: Gallimard, 1946.

—. Sous l'invocation de Saint Jérôme: Édition augmentée de textes annexes. Paris: Gallimard, 1997. First edition Paris: Gallimard, 1946.

Maggioni, Giovanni Paolo, ed. Iacopo da Varazze, Legenda aurea: Edizione critica, 2 vols. Florence: SISMel Edizioni del Galluzzo, 1998.

Maisano, Riccardo, ed. Giovanni Mosco, Il prato: Presentazione, traduzione e commento. Naples: D’Auria, 1982.

Marcel, Jean [pseudonym of Jean-Marcel Paquette]. Hypatie ou La fin des dieux. Montréal: Leméac Éditeur, 1989. 
—. Jêrome ou De la traduction. Montréal: Leméac Éditeur, 1990.

. Sidoine ou La dernière fête. Montréal: Leméac Éditeur, 1993.

Morisi Guerra, Anna. "La leggenda di San Girolamo: Temi e problemi tra Umanesimo e Controriforma." Clio 23.1 (1987): 5-33. , ed. Erasmo da Rotterdam, Vita di San Girolamo: Edizione critica. L'Aquila: Japadre editore, 1988.

Mousli, Béatrice. Valery Larbaud. Paris: Flammarion, 1998.

Vaccari, Alberto. "Le antiche vite di S. Girolamo." In Miscellanea Geronimiana, Scritti varii pubblicati nel XV centenario dalla morte di san Girolamo, con introduzione di Vincenzo Vannutelli, edited by Vincenzo Vannutelli, 1-18. Rome: Tipografia Poliglotta Vaticana, 1920. 


\section{ABSTRACT}

The paper examines three examples of Saint Jerome's contemporary reception. First, in Sous l'invocation de Saint Jérôme, the essay by the French writer and translator Valery Larbaud (1946), Jerome's life is imagined as the large city of Hiéronymopolis where three itineraries are possible: one that is imaginary to Stridon, Rome, and Bethlehem; one that is iconographical through the paintings of Raffaello, Correggio, and Domenichino, and one that is literary through Jerome's works, divided into many "city districts," where an impressive bridge, the Vulgata, connects Jerusalem to Rome. - In the eccentric novel Jérôme ou de la traduction by the French-Canadian writer Jean Marcel (1990), Hieronymus's famous lion narrates the main episodes of the Saint's life, especially regarding his translations. This is an existential metaphor for the passage from the ancient eastern world to early Christian Rome. The poetic movie by the Brasilian director Júlio Bressane, São Jerônimo (1999), is not a biographical reconstruction of Jerome's life, but rather a fresco, which consists of some moments of his life and some iconic symbols (the skull, the lion, the desert).

KEYWORDS: Jerome's reception, Valery Larbaud, Jean Marcel, Júlio Bressane, translation 
POSMRTNO ŽIVLJENJE SVETEGA HIERONIMA:

VIDIKI NJEGOVE RECEPCIJE V DVAJSETEM STOLETJU

\section{IZVLEČEK}

Članek obravnava tri primere sodobne recepcije svetega Hieronima. Prvič, v Sous l'invocation de Saint Jérôme, eseju francoskega pisatelja in prevajalca Valeryja Larbauda (1946), je Hieronimovo življenje predstavljeno kot veliko mesto Hiéronymopolis, kjer so možne tri poti. Ena je namišljena, v Stridon, Rim in Betlehem; druga je ikonografska, skozi slike Rafaela, Correggia in Domenichina; zadnja je literarna, skozi Hieronimova dela, razdeljena na številne »mestne četrti«, kjer mogočen most, Vulgata, povezuje Jeruzalem $\mathrm{z}$ Rimom. - V ekscentričnem romanu Jérôme ou de la traduction francosko-kanadskega pisatelja Jeana Marcela (1990) Hieronimov slavni lev pripoveduje o osrednjih epizodah iz svetnikovega življenja, zlasti o njegovih prevodih. To je eksistencialna metafora za prehod iz sveta starodavnega Vzhoda v zgodnjekrščanski Rim. - Poetični film brazilskega režiserja Júlia Bressanea São Jerônimo (1999) ni biografska rekonstrukcija Hieronimovega življenja, temveč freska, sestavljena iz trenutkov njegovega življenja in osrednjih simbolov (lobanja, lev, puščava).

KLJUČNE BESEDE: Hieronimova recepcija, Valery Larbaud, Jean Marcel, Júlio Bressane, prevajanje 